\title{
Interactive effects of chronic anthropogenic disturbances on Prosopis woodland structure in the Central Monte, Argentina
}

\author{
Carolina R. Szymañski ${ }^{12,1} ;$ Pablo E. Villagra ${ }^{122} ; V_{\text {aleria Aschero }}^{1 / 3} \&$ Juan A. \\ AlvareZ ${ }^{1,2}$ \\ ${ }^{1}$ Instituto Argentino de Nivología, Glaciología y Ciencias Ambientales, CCT Conicet Mendoza, Argentina. ${ }^{2}$ Facultad de \\ Ciencias Agrarias, Universidad Nacional de Cuyo. Chacras de Coria, Mendoza, Argentina. ${ }^{3}$ Facultad de Ciencias Exactas y \\ Naturales, Universidad Nacional de Cuyo. Parque General San Martín, Mendoza, Argentina.
}

\begin{abstract}
Aвstract. In drylands all over the world, chronic anthropic disturbances are relevant factors for woodland degradation. Different disturbances can potentially interact to change vegetation structure. Knowing woodland structure is crucial for better predicting forest dynamic because trees of different sizes significantly affect the regeneration processes, number of saplings and young trees, crown traits and competition attributes. Throughout the Monte biogeographic region, grazing and wood extraction are the main anthropogenic disturbances on Prosopis dry woodlands that can generate modifications in key ecosystem processes. First, we aimed to assess woodland structure at sites under chronic anthropic disturbances. Subsequently, we explored how the combination of grazing and wood extraction affected the population structure of $P$. flexuosa considered by classes: seedlings, saplings and adults. We found that sites under disturbances presented a high density of trees of smaller sizes. Besides, the interaction effect between grazing and wood extraction depended on the intensities of each of the disturbances. The combination of high intensities of both grazing and wood extraction negatively affected the abundance of all classes, but low or moderate grazing intensities combined with high wood extraction had a positive effect on the abundance of saplings and adults. High intensities of co-occurring disturbances decreased seedling abundance affecting forest recruitment which also was negatively reflected in sapling and adult abundance. However, the combination of low or moderate grazing and high wood extraction generated a woodland structure characterized by few seedlings, and many saplings and adult trees of small size. Application of management options (e.g., spatial or temporal separation of human use, programmed management of grazing and wood extraction intensities or planned practices as wood removal for local use) should contribute to enhance the provision of ecosystem services in Prosopis sp. woodlands without risking regeneration persistence and improving the woodland structure.
\end{abstract}

[Keywords: chronic anthropogenic disturbance, dry woodlands, wood extraction, co-management practices, grazing, interactive disturbances]

Resumen. Efectos interactivos de los disturbios antrópicos crónicos sobre la estructura forestal de Prosopis en el Monte Central, Argentina. En las zonas áridas de todo el mundo, los disturbios antrópicos crónicos son factores relevantes para la degradación de los bosques. La combinación de distintos disturbios puede cambiar la estructura de la vegetación, lo cual tiene implicancia en los procesos de regeneración, el número de plántulas y árboles jóvenes, las características de la copa y los atributos de competencia. En la región biogeográfica de Monte, el pastoreo y la extracción de madera son los principales disturbios antrópicos en los bosques de Prosopis que pueden generar modificaciones en procesos clave de los ecosistemas. Primeramente, nuestro objetivo fue evaluar la estructura del bosque en sitios bajo disturbios antrópicos crónicos. Posteriormente, exploramos cómo las posibles interacciones entre pastoreo y extracción de madera afectaron la estructura de la población de $P$. flexuosa, considerada por clases: plántulas, juveniles y adultos. Los sitios sometidos a disturbios presentaron una alta densidad de árboles de menor tamaño. Además, la co-ocurrencia de altas intensidades de disturbio disminuyó la abundancia de plántulas, afectando el reclutamiento forestal, lo cual también afectó negativamente la abundancia de renovales y adultos. Sin embargo, la combinación de pastoreo bajo o moderado y alta extracción de madera generó una estructura boscosa con pocas plántulas y muchos renovales y adultos de pequeño tamaño. Aplicar opciones de manejo como la separación espacial o temporal del uso humano, el manejo programado de las intensidades de ganadería, o prácticas planificadas como la extracción de madera para uso local contribuiría a mejorar la provisión de servicios ecosistémicos en bosques de Prosopis sp. sin afectar la regeneración y mejorando la estructura del bosque.

[Palabras clave: disturbios antrópicos crónicos, bosques de zonas áridas, extracción de madera, prácticas de co-manejo, pastoreo, disturbios interactivos]

Editora asociada: Ana Cingolani

Editor junior: Alejandro Loydi
Recibido: 26 de Junio de 2020

Aceptado: 12 de Octubre de 2021

cszymanski@mendoza-conicet.gob.ar 


\section{INTRODUCTION}

Dryland biomes occupy approximately $41 \%$ of the world's land surface and are home to one-third of the world's population (Bastin et al. 2018). These ecosystems deserve special attention due to the high fragility they present in the face of anthropic pressure (Whitford 2002). Woodland structure of drylands is determined by climate and edaphic properties, especially water availability, and it is also particularly sensitive to the impact of human activities because of their low regeneration capacity (Malagnoux et al. 2007; Villagra et al. 2009; Albuquerque et al. 2018). Understanding the effects of factors driving woodland population dynamics can improve conservation and management programs (Piraino et al. 2016).

Chronic anthropogenic disturbances derive from the human use of woodlands to support livelihoods; for example, the extraction of deadwood and non-timber woodland products, grazing or hunting (FAO 2016). Opposite to large-scale disturbances such as habitat loss and fragmentation, chronic disturbances are diffuse and more frequent, and operate at small spatial scales. Therefore, they are not expected to cause sudden and complete changes to the environment (Ribeiro et al. 2015). However, these disturbances have been recognized as a determining factor in the woodlands decline of developing countries because their effects could be cumulative over the time (Martorell and Peters 2005). Overgrazing and unplanned extraction of woodland products are among the main chronic disturbances that can change vegetation structure, cause local species extinctions, affect ecological processes and, finally, produce land degradation (Leal et al. 2005; Martorell and Peters 2005; Ribeiro et al. 2015). Chronic disturbances modified the structure of woodlands and turned them into alternative states such as lands dominated by shrubs (Ribeiro et al. 2015). Knowing woodland structure is crucial for better predicting forest dynamic because trees of different sizes significantly affect the regeneration processes, the number of saplings and young trees, crown traits, and competition attributes (Podlanski et al. 2019). It is generally accepted that the combined effects of multiple chronic disturbances influence ecosystem processes, but the effects of those interactions on plant population dynamics remain poorly understood (Mandle and Ticktin 2012).
The Monte biogeographic region is a subtropical warm temperate desert located in western Argentina (Abraham et al. 2009), where Prosopis flexuosa is the main tree species, reaching 250 years of longevity (Alvarez and Villagra 2009). From the ecosystem point of view, $P$. flexuosa is considered a nurse species because it increases soil fertility by contributing organic matter under its canopy, promoting interactions between animals and plants (Rossi and Villagra 2003; Villagra and Alvarez 2019). Also, this tree species provides important ecosystem services such as shade and forage for livestock, food, firewood, and materials for house building (Alvarez and Villagra 2009). The history of anthropic and natural disturbances has driven to the desertification of large areas of Prosopis woodlands, reducing the extent of its occurrence and simplifying its structure (Villagra et al. 2009).

Nowadays, grazing and wood extraction (the main productive and subsistence activities in Prosopis woodlands) can modify key ecosystem processes (Meglioli et al. 2014). The effects of grazing have been studied to a deeper extent than those produced by wood extraction. Grazing has differential effects over different plant life cycle phases (Aschero et al. 2016). In the initial stages, grazing can facilitate germination and seed dispersal processes (Campos and Ojeda 1997) and can also decrease above- and belowground competition from herbaceous vegetation towards woody seedlings, favoring their establishment and persistence. Once woody plants reach the sapling stage, they become much less vulnerable, but competition, nutrient limitations and disturbances such as herbivory can combine to slow down sapling development and prolong the time they require to reach the adult stage (Archer et al. 2017). Likewise, disturbances such as grazing or wood extraction can cause the destruction of the apical bud in P. flexuosa saplings, favoring vegetative regeneration (regrowth) and generating individuals with multiple stems (Alvarez et al. 2011a).

Wood is an essential component of forests which provides regeneration substrate for some plants and refuge for multiple organisms (Morrissey et al. 2014). Thus, extraction of deadwood on the ground can reduce suitable sites for germination and establishment of seedlings. Also, the damage produced during the wood extraction process could negatively affect the initial development stages of a 
population. There is incipient evidence that wood removal does not have negative effects on seed production of $P$. flexuosa, understory plants and soil properties in Prosopis woodlands, but results are not conclusive (Vazquez et al. 2011). Although wood extraction and grazing commonly occurs simultaneously in arid lands, their potential interactive effect is still poorly understood.

Considering what has been stated so far, we hypothesize that chronic disturbances, despite representing a low intensity disturbance, are determinant of $P$. flexuosa woodland structure in the Monte of Argentina, and their effects could be differential among stage classes, specially affecting the most vulnerable stages, as regeneration (Villagra et al. 2004). Also, simultaneous disturbance agents can interact and produce an effect greater than the sum of their individual effects; for example, wood extraction increases the possibilities of cattle grazing - which leads to greater soil erosion, increased trampling and decreased suitable sites for germination-, negatively affecting forest regeneration. Our specific objectives were to: 1) assess woodland structure in sites under different long-term land management types and 2) explore how the potential interactions between grazing and wood extraction, affected the population structure of $P$. flexuosa. The final goal of this study is to generate information for the regional management of Prosopis woodlands and to contribute to the knowledge of the functioning of dryland ecosystems in the face of low intensity disturbances sustained over time.

\section{Materials and Methods}

\section{Study site}

The study area is located in the Monte biogeographic region $\left(24^{\circ} 35^{\prime} \mathrm{S}\right.$ to $44^{\circ} 20^{\prime}$ $\mathrm{S}$ and from $62^{\circ} 54^{\prime} \mathrm{W}$ to $69^{\circ} 5^{\prime} \mathrm{W}$ ) (Figure 1). It is characterized by semiarid to arid climate, marked seasonality and wide daily temperature range. The average annual temperature varies from $\mathrm{N}$ to $\mathrm{S}$ between 17.5 and $13{ }^{\circ} \mathrm{C}$, respectively. Total annual precipitation varies between 50 and $350 \mathrm{~mm}$; it is concentrated in Spring and Summer, and shows a decreasing gradient from east to west (Labraga and Villalba 2009).

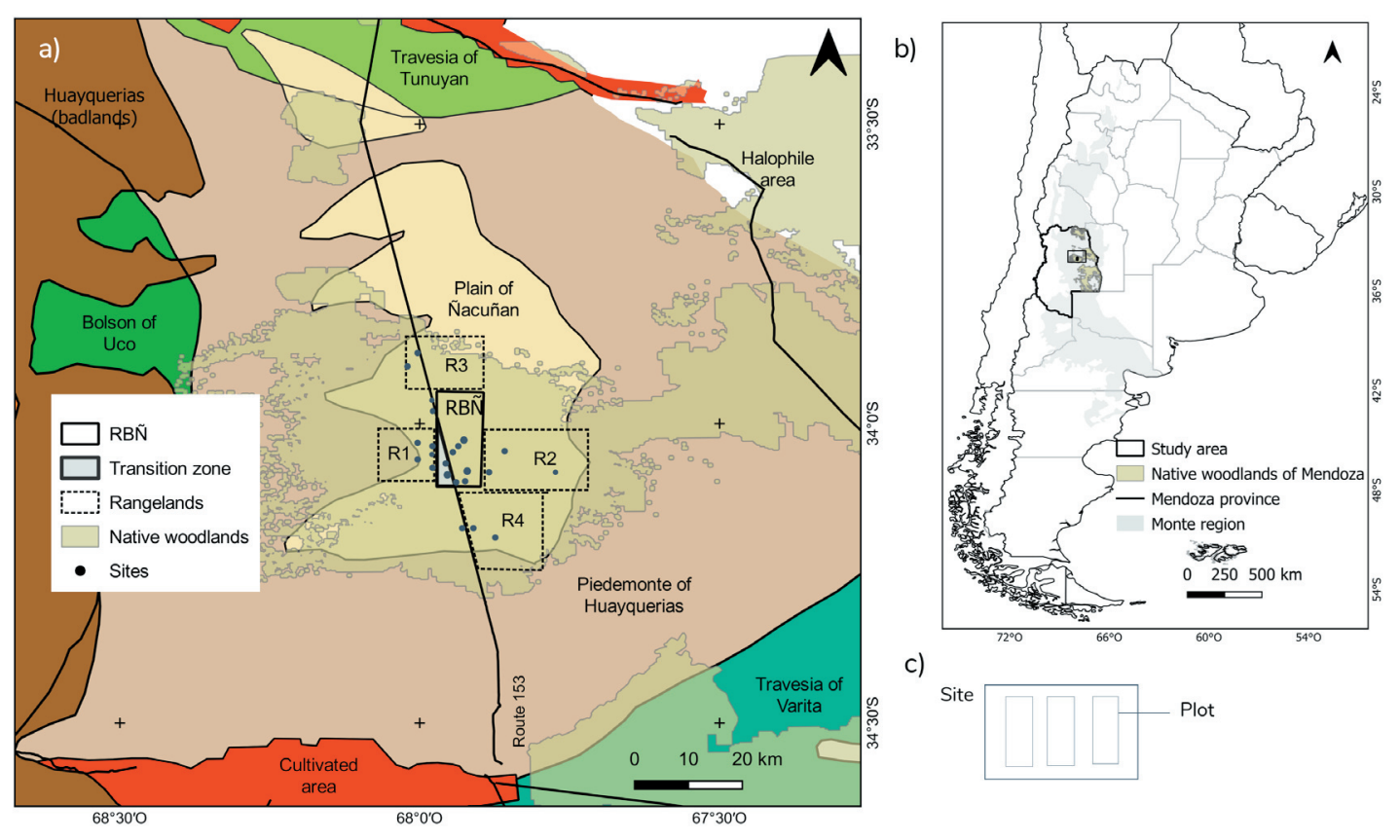

Figure 1. Study area location $(a, b)$ and sites (a) within Prosopis woodlands of the Central Monte, in areas with high grazing disturbance (rangelands with continuous grazing management: R1 and R3; rangelands with rotational grazing management: R2 and R4), area with wood extraction (transition zone) and undisturbed area (reserve) (a). Surfaces of the private cattle ranches are approximate. Schema of plots at each site (c).

Figura 1. Localización del área de estudio $(\mathrm{a}, \mathrm{b})$ y de los sitios (a) de muestreo en bosques de Prosopis del Monte Central, en áreas con fuerte disturbio ganadero (campos con manejo continuo: R1 y R3; campos con manejo rotativo: R2 y R4), área con extracción de madera (zona de transición) y área no disturbada (reserva) (a). Las superficies de los campos ganaderos son aproximadas. Esquema de las parcelas establecidas por cada sitio (c). 
The vegetation is a mosaic composed by a) shrub steppe dominated by Zigophyllaceae species, b) edaphic steppes of halophytic shrubs such as Suaeda divaricata, Atriplex spp. and Alleronfea vaginata, and c) azonal woodlands dominated by species of Prosopis genus or 'algarrobales' that reach between 15 and $30 \%$ of tree cover (Villagra et al. 2004). In the 'algarrobales', P. flexuosa trees are commonly associated with shrubby and small trees such as Larrea divaricata, Geoffroea decorticans, Capparis atamisquea and Bulnesia retama.

The study area is placed in the Nacuñán plain, which was formed by the accumulation of Andean sediments during the upper Cenozoic and Quaternary periods (Guevara et al. 1997), conforming an alluvial fan with a west-east disposition. Therefore, Prosopis woodlands are located in (micro)gradient with poor soils on the west and an enrichment of the soil to the east by accumulation of sediments, related to the transition between the 'Huayquerias' (i.e., lands extensively eroded by water and wind due to lack of vegetation know as 'badlands') and the sedimentary basin (Figure 1) (Capitanelli 1972). Also, the Nacuñán plain presents temporary streams and deep layers of clay that could provide additional water for plant growth (Torres 2001; Tanquilevich 1971).

In relation to historical use, trees all over the region were felled at the beginning of the 19th century to extract logs, coal and poles. The forest products were used first for charcoal and gas production, and later for the supply of wood for the wine and furniture industries. After 1916, forest clearing increased the growth of heliophytic grasses and promoted the expansion of cattle grazing (Abraham and Prieto 1999). Since then, cattle grazing has progressively increased and has become the dominant production system in the region. In parallel, wood exploitation has decreased (Aschero and García 2012). The current woodland constitutes a secondary regrowth forest characterized by the presence of multistemmed trees.

We worked in areas with different longterm land management types: the Nacunán Biosphere Reserve $\left(34^{\circ} 03^{\prime} \mathrm{S}-67^{\circ} 58^{\prime} \mathrm{W}\right)$, the transition zone, and surrounding private rangelands (Figure 1a). In the reserve, grazing and extractive activities have been excluded for nearly 50 years. The response to the exclusion of a disturbance agent is inherently linked to disturbance intensity, site-specific properties and time of cessation of disturbance. It has been observed that after 30-40 years of domestic grazing removal, the increase of plant biomass (i.e., grasses and shrubs) led to a significant spatial rearrangement of plant patches and modifications of certain functions, such as soil stability and nutrient cycling (Valone and Sauter 2005; Cramer et al. 2008; Tabeni et al. 2017). As noted in the reserve, 50 years of domestic grazing removal promoted an increment in the abundance-dominance or frequency of the main palatable grasses as well as some species of shrubs (Rossi 2004). Also, the increase of plant cover restored the spatial arrangement of vegetation patches and consequently reestablished landscape connectivity (Tabeni et al. 2016). Thus, for the purpose of this study, the reserve can be considered as an undisturbed area.

The surrounding private rangelands present different combinations of grazing and wood extraction (i.e., people extract stems from living trees mainly for use as poles and also deadwood for domestic use) (Figure 2a and $2 b)$. As grazing is the main disturbance in those rangelands, we referred to them as areas with high grazing disturbance to simplify identification. However, disturbances, grazing and wood extraction can be jointly present in rangelands. In the transition zone, a local community of approximately fourteen families extract wood for domestic use, including coarse woody debris and stems and deadwood from living trees. This area presents an intense extraction pressure, considering the time of deadwood production in Prosopis woodlands ( $\sim 20$ years) (Alvarez et al. 2011a). As grazing disturbance is not present in this area, we referred to it as an area with wood extraction disturbance.

\section{Field methods}

Sample design considered land management type and woodland heterogeneity. We established 23 sites within the 'algarrobal' community patches, in woodlands areas with different land management types, taking as a base the vegetation map of GonzálezLoyarte et al. (2000). Sites were separated from each other by at least $500 \mathrm{~m}$. Ten sites were randomly selected in the undisturbed area and 13 sites were established in areas with chronic disturbances ( 3 in the area with wood extraction and 10 in areas with high grazing disturbance). Then, we arranged three sampling plots within each site (except 

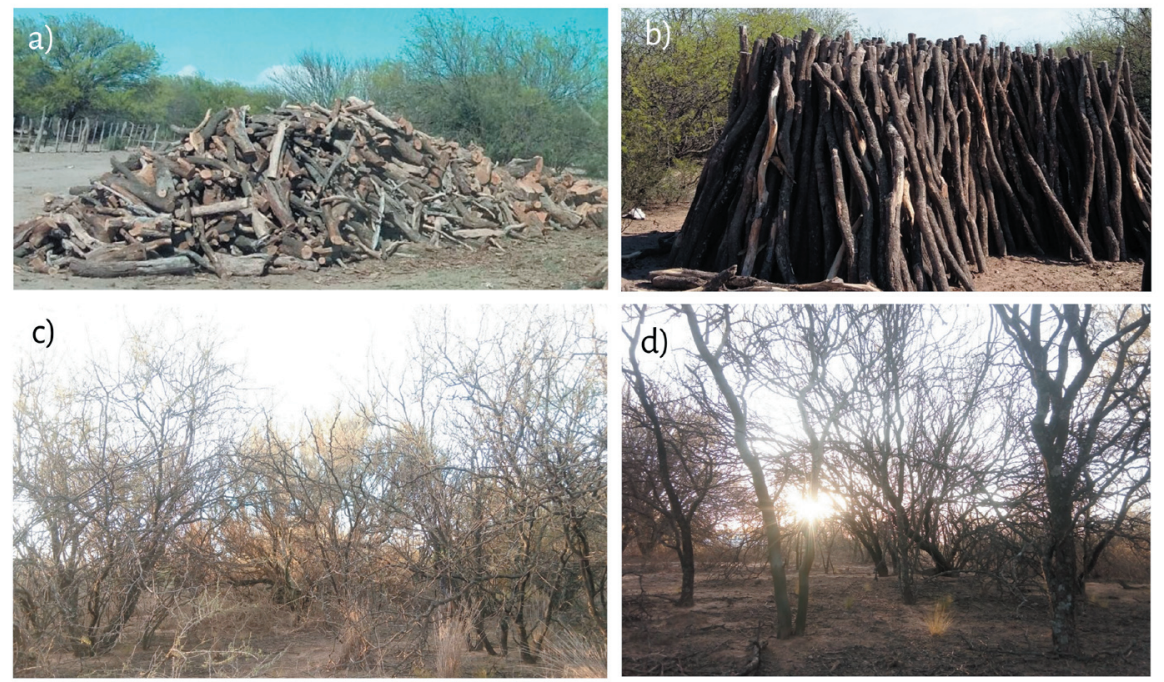

Figure 2. Wood accumulation for posts and firewood in rangelands ( $a$ and b) (ph: E. Barrio). Vegetation stands with small trees and high density (c and d) (ph: C. Szymañski).

Figura 2. Acumulación de madera para postes y leña en campos ganaderos (a y b) (ph: E. Barrio). Parches de vegetación con árboles pequeños y gran densidad (c y d) (ph: C. Szymañski).

for a site where two plots were established) according to logistic possibilities. Plots were 20x50 m, placed at least $100 \mathrm{~m}$ apart from each other ( $\mathrm{n}=68$ plots) (Figure 1a and 1c).

\section{Woodland structure survey}

We registered variables related to woodland structure in each plot: number of $P$. flexuosa trees, number of stems in each individual of P. flexuosa, basal diameter of each stem (using diameter tape or digital caliper), total tree height (with Velmex digital hypsometer, resolution: $0.1 \mathrm{~m}$ ), crown dimensions (major and minor diameter using diameter tape). Considering that most trees are multistemmed, we calculated the equivalent basal diameter (EBD) for each tree with the next formula, following the procedure used by Alvarez et al. (2006). Formula includes dab (diameter at the height of the base) of each stem.

$\mathrm{EBD}=2 \sqrt{ }\left\{\left\{\pi\left(\mathrm{dab}_{1} / 2\right)^{2}+\pi\left(\mathrm{dab}_{2} / 2\right)^{2}+\pi\left(\mathrm{dab}_{3} /\right.\right.\right.$ $\left.\left.2) 2+\ldots .+\pi\left(\mathrm{dab}_{\mathrm{n}} / 2\right)^{2}\right\} / \pi\right\}$

Then, we estimated total density (trees/ha), stems/ha and canopy coverage $\left(\mathrm{m}^{2} / \mathrm{ha}\right)$.

Finally, we classified trees of $P$. flexuosa in stage-size classes as adults $(\mathrm{EBD}>7.5 \mathrm{~cm})$, saplings (EBD between 7.5 and $1 \mathrm{~cm}$ ) and seedlings $(\mathrm{EBD}<1 \mathrm{~cm})$ (Villagra et al. 2005;
Aschero and García 2012). The seedlings class is characterized for being a critical period of great mortality, where the seedling needs to establish. After the seedling stage, survival is probably high (Villagra et al. 2004). The category of saplings and adults were established according to the management practices in the area. Individuals with basal diameters greater than $7.5 \mathrm{~cm}$ were considered adults because they are used as firewood and poles for vineyards (Villagra et al. 2005). We estimated the number of trees per hectare for each stage size-classes (hereafter abundance of adults, saplings and seedlings) from the number of trees per plot belonging to each class.

\section{Disturbance indices}

Since chronic disturbances produce gradual changes in ecosystems, they need to be measured on a continuous scale that quantifies the degree of disturbance, rather than using a dichotomic scale (Martorell and Peters 2005). Thus, we built quantitative indices of grazing and wood extraction in the same plots to analyze the effects of chronic disturbances on the stand structure of Prosopis woodlands. In private rangelands and in the transition zone, we counted the number of branch collars in all trees of the plots as a sign of branch removal (hereafter, wood extraction index). Wood extraction index was null in the reserve. 
Subsequently, we approximated grazing intensity (hereafter, grazing index) in plots of the rangelands by visually estimating fresh cow dung cover using a $1 \times 1 \mathrm{~m}$ quadrat, placed 30 times systematically within each plot. The sum of cow dung cover in all the quadrants was established as the grazing index per plot. Grazing was null in the reserve and the transition zone.

\section{Data analysis}

First, we used principal component analysis (PCA) to describe the main trends of sites' variation according to structure. The data recorded in the plots corresponding to the same site were averaged to obtain the values per site. In the PCA we included the structure variables total density of trees, crown diameter, height, canopy coverage and stems/ha (Di Rienzo et al. 2008). Later, we performed generalized linear mixed models (GLMM) to analyze the combined effects of chronic anthropogenic disturbances on abundance of each stage size-classes (i.e., adults, saplings and seedlings), assuming a Poisson distribution of errors. Therefore, the abundance of each class was established as response variable and disturbance indices were set up as fixed effects. Disturbance indices were scaled dividing the $\mathrm{x}$ value by their standard deviations before being incorporated to GLMM. There was not a correlation between disturbance indices used as explanatory variables $(\mathrm{rho}=-0.08, \mathrm{P}>0.05)$. We explored the potential interactive effects of grazing and wood extraction including the interaction between wood extraction index and grazing index in the GLMM. Considering that plots corresponding to the same site have similar history, management and environment, we included the site in GLMM as random effect (Bates et al. 2014). We calculated $R^{2}$ marginal $\left(R^{2} M\right)$ and $R^{2}$ conditional $\left(R^{2} C\right)$ coefficients to assess the goodness of fit. $R^{2} \mathrm{M}$ represents variance of fixed factors while $R^{2} C$ represents the variance explained by both fixed and random effects (Nakagawa and Schielzeth 2013). We used graphic methods to test assumptions of normality and homogeneity of residuals.

We performed all analyses using R v.3.2.5 environment and language (R Core Team 2018) and Infostat program (Di Rienzo et al. 2008). We performed principal components analysis with Infostat program. We used 'lme4' (Bates et al. 2018), 'fitdistrplus' (Delignette-Muller and Dutang 2015), 'DHARMa' (Hartig 2020), 'emmeans' (Lenth 2021) and 'MuMIn' (Barton 2020) packages to perform GLMM.

\section{Results}

\section{Relationship among sites with different land management types}

The PCA analysis indicated that height, crown diameter, total density and stems/ha were the variables with the best projection on PC1 (Figure 3). The first component explained $\sim 60 \%$ of the variability. Sites with

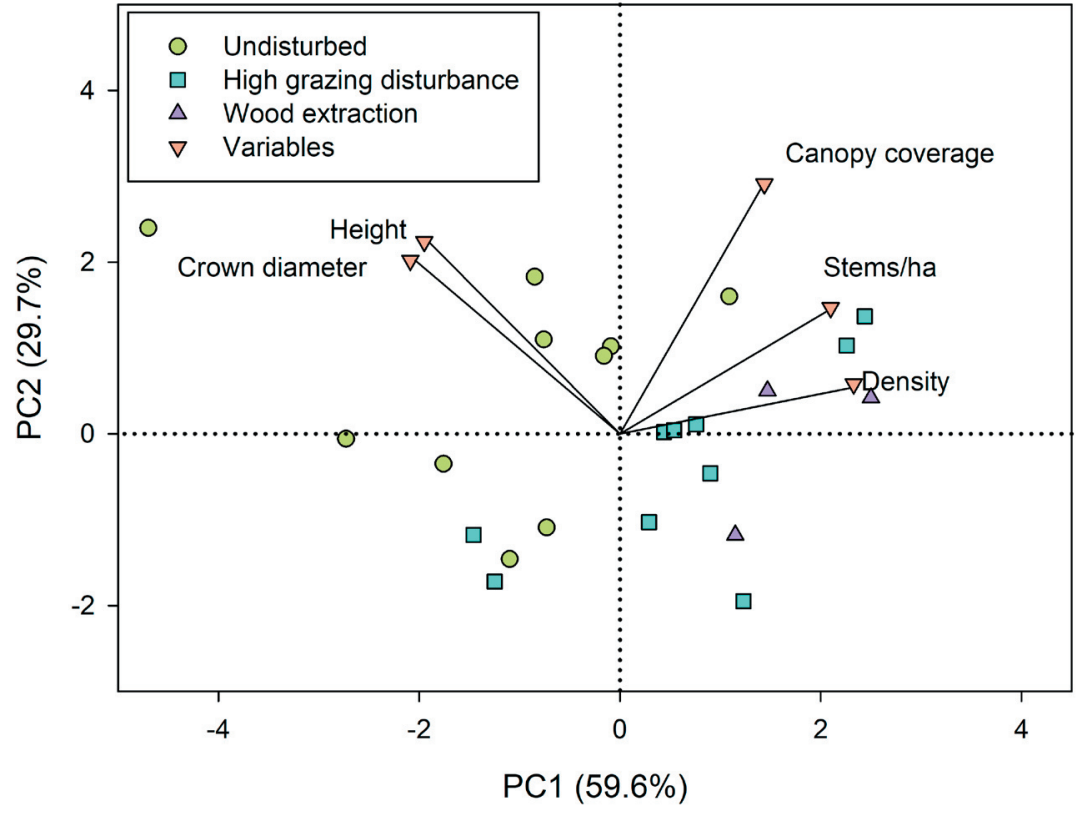

Figure 3. Principal components analysis to describe site similarities and structural variables. Principal components 1 and 2 are represented.

Figura 3. Análisis de componentes principales para describir las similitudes entre sitios y las variables estructurales. Se representan componentes principales 1 y 2 . 

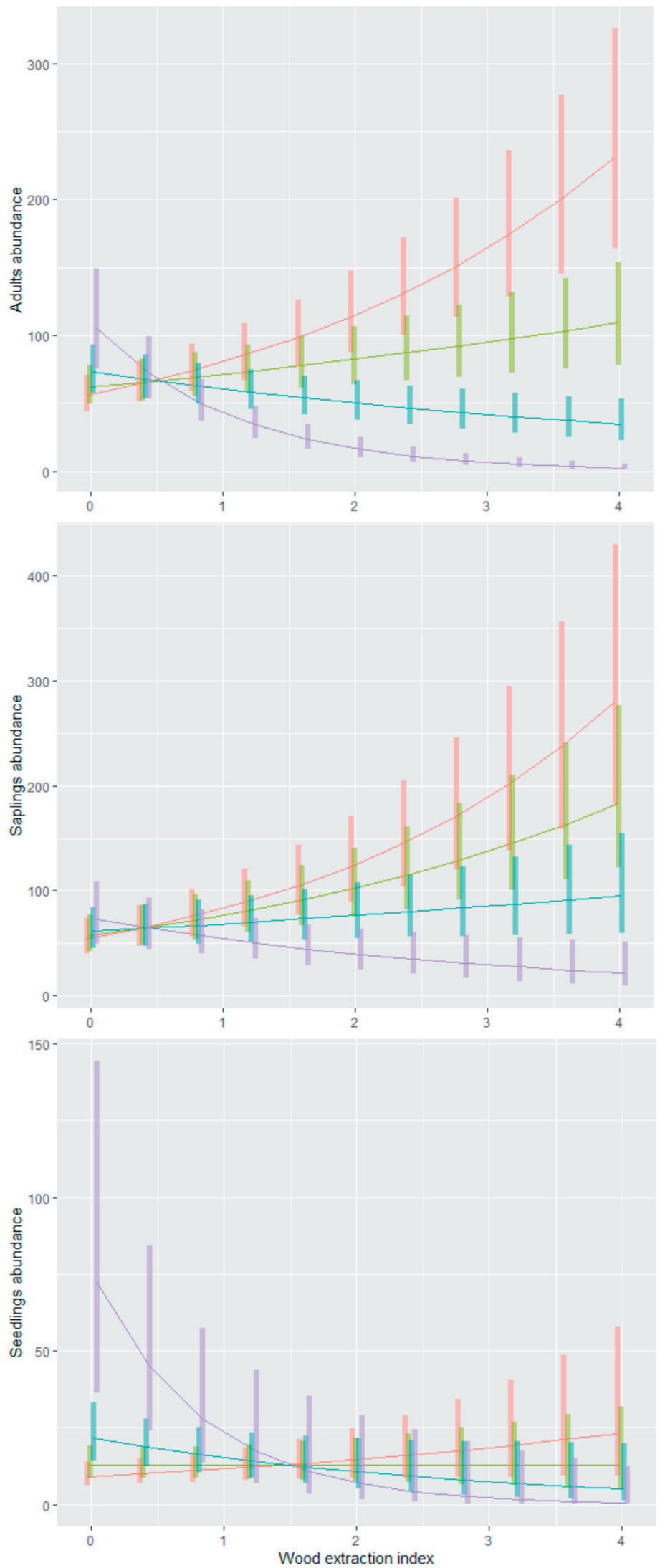

Grazing index

$+0$

$+0.54$

$+1.38$

$+3.31$

\section{Grazing index}

$+0$

- 0.54

$+1.38$

+ 3.31

Figure 4. Effects of the interaction between grazing and wood extraction indices on the abundance of adults, saplings and seedlings. Four levels are represented for grazing Grazing index index: null, mean, + 0 mean+standard deviation + 0.54 and maximum.

$+1.38$

$+3.31$

Figura 4. Efectos de la interacción entre indicadores de ganadería y extracción de madera sobre la abundancia de adultos, juveniles y plántulas. Se representan sólo cuatro niveles del índice de uso ganadero: nulo, medio, medio+una desviación estándar y máximo. 
chronic disturbances mainly presented higher densities and smaller sizes of individuals, and they were arranged to the right of the graph, while undisturbed sites presented the opposite characteristics and were grouped to the left of the graph.

\section{Abundance of stage size-classes according chronic disturbances}

The GLMM results indicated that the combination of high intensities of both disturbances negatively affected all stage classes, decreasing their abundances (Table 1 ; Figure 4). However, intermediate intensity of grazing found in private rangelands combined with low, moderate, or high wood extraction intensities increased the abundance of adults and saplings (Figure 4). Particularly, the combination of low grazing intensity and high wood extraction increased the abundance of adults and saplings between three and five times more than low intensities of both disturbances (Figure 4).

The highest seedlings abundance was observed at high grazing intensity and low wood extraction. For low grazing intensity, high wood extraction increased seedlings abundance. The abundance of seedlings did not show variation for intermediate intensity of grazing found in private rangelands combined with low, medium, or high intensities of wood extraction (Figure 4). Disturbances explained between 17 and $25 \%$ of the variance in stage classes abundance (variance of fixed effects). Large variation in GLMM was associated to site as random effects ( $72-78 \%)$ (Table 1$)$.

\section{Discussion}

The lack of knowledge about the combined action of anthropic disturbances makes it difficult to implement sustainable practices for the use of natural resources. This study is the first to quantify the interaction effect of two common disturbances of arid lands, grazing and wood extraction. Since the global effect of the chronic disturbances results from their integrated effects on the different stages of the life cycle of a species, we analyzed chronic anthropogenic disturbances effects on the population structure considered by stages classes. We found that the combination of high intensities of grazing and wood extraction negatively affected seedlings abundance, according to disturbance intensities found in the study area. Aschero and García (2012) reported that the positive effects of grazing on seedling emergence offset the negative effects of livestock on seed production and seedling survival; thus, grazing does not have a net effect on tree recruitment. Conversely, in this work, we show that the combination of high intensities of both grazing and wood extraction decreased seedling abundance and, therefore, regeneration in P. flexuosa woodlands. Wood is an important functional component of forest ecosystems which provides regeneration substrate for plants, among other effects (Morrissey et al. 2014). Elimination of wood reduces the regeneration microsites and may allow more access of livestock into the stand, increasing herbivory, trampling and soil erosion by cattle, and consequently, decreasing recruitment. Disturbances favor the presence of highly erodible soils that

Table 1. Results of adjusted models for abundance per stage-classes of Prosopis flexuosa according to different disturbances in the Monte Central, Argentina. WE index: wood extraction index; $R^{2} M: R^{2}$ marginal; $R^{2} C: R^{2}$ conditional.

Tabla 1. Resultados de los modelos ajustados para la abundancia de Prosopis flexuosa por clase en relación con los distintitos disturbios en el Monte Central, Argentina. WE index: índice de extracción de madera; $\mathrm{R}^{2} \mathrm{M}$ : $\mathrm{R}^{2}$ marginal; $\mathrm{R}^{2} \mathrm{C}: \mathrm{R}^{2}$ condicional.

\begin{tabular}{clcccc}
\hline Adjusted Model & Fixed effects & Estimate & Std. error & Z value & P value \\
\hline Adults abundance & Intercept & 4.02 & 0.12 & 33.29 & $<0.0001$ \\
$\mathrm{R}^{2} \mathrm{M}=\mathbf{2 5 \%}$ & Grazing index & 0.19 & 0.05 & 4.26 & $<0.0001$ \\
$\mathrm{R}^{2} \mathrm{C}=97 \%$ & WE index & 0.35 & 0.04 & 9.81 & $<0.0001$ \\
& Grazing index $\times$ WE index & -0.39 & 0.04 & -10.51 & $<0.0001$ \\
Saplings abundance & Intercept & 3.99 & 0.15 & 26.02 & $<0.0001$ \\
$\mathrm{R}^{2} \mathrm{M}=19 \%$ & Grazing index & 0.09 & 0.05 & 1.82 & 0.07 \\
$\mathrm{R}^{2} \mathrm{C}=98 \%$ & WE index & 0.41 & 0.04 & 9.28 & $<0.0001$ \\
& Grazing index $\times$ WE index & -0.22 & 0.04 & -5.34 & $<0.0001$ \\
Seedlings abundance & Intercept & 2.21 & 0.21 & 10.42 & $<0.0001$ \\
$\mathrm{R}^{2} \mathrm{M}=17 \%$ & Grazing index & 0.63 & 0.11 & 5.87 & $<0.0001$ \\
$\mathrm{R}^{2} \mathrm{C}=95 \%$ & WE index & 0.24 & 0.12 & 1.95 & 0.05 \\
& Grazing index $\times$ WE index & -0.43 & 0.13 & -3.28 & $<0.005$ \\
\hline
\end{tabular}


hinder germination (Muñoz-Rojas et al. 2016). Furthermore, the role of vegetation patches is crucial in promoting germination and seedling establishment in arid lands because they provide water and nutrients (Aguiar and Sala 1999; Snyman 2004; Muñoz-Rojas et al. 2016). Anthropogenic disturbances can change vegetation spatial configuration and even reduce the cover of patches, consequently reducing the facilitation process and decreasing recruitment (Aguiar and Sala 1999). Our results are highly relevant to forest conservation as they indicate that the combination of high intensities of productive and subsistence activities, such as grazing and wood extraction, would negatively affect regeneration. In accordance with this, Martorell and Peters (2005) reported that different anthropogenic disturbances can act synergistically on the population density of the endemic cacti Mammillaria pectinifera, and that their combined effects are more detrimental than individually. However, the abundance of seedlings did not vary for intermediate intensity of grazing found in private rangelands combined with low, medium, or high intensities of wood extraction. The highest seedlings abundance was observed for combination of high intensity of grazing and low wood extraction because grazing facilitates germination and seed dispersal processes (Campos and Ojeda 1997).

Similar results were found in saplings and adults, whose abundances decreased when high intensities of both disturbances (grazing and wood extraction) took place simultaneously. These results could reflect a consequence of the negative effects on the early stages. Disturbances can prolong the time saplings require to reach the adult stage (Archer et al. 2017). Even for the study site, previous research found that the transition probability from sapling to the next stages was lower under grazing disturbance than inside the reserve (Aschero et al. 2016). However, the combination of low or moderate grazing and high wood extraction increased the adults and saplings. Disturbances as grazing and wood extraction can produce the destruction of apical bud of saplings favoring their resprout and generating multi-stemmed trees (Alvarez et al. 2011a). Furthermore, clumping of seedlings and young trees was associated with grazing sites because cattle facilitate the germination process (Aschero and García 2012). Thus, areas with chronic disturbances presented stands conformed by small multi-stemmed trees, which indicate that disturbances decrease the size of trees but increase their abundance, facilitating woody encroachment (Asner et al. 2003). This could be observed in stands of closed woodland with a high density of individuals and difficult access, near cattle pens and watering points (Fig. 2c y 2d). Disturbances can lead ecosystems to alternative states with different structural and functional attributes (Chillo and Ojeda 2014). Previous studies conducted in drylands have reported that the presence of chronic disturbances over time has led to the formation of different vegetation structures (Ribeiro et al. 2015). According to Cesca and collaborators (2014), other disturbances such as recurring fire events have changed the structure of $P$. flexuosa woodland in southern Mendoza. Woodland has degraded to shrubland structure where the population is dominated by individuals of small size and multiple stems (Cesca et al. 2014). Changes in the woodland structure can have deep consequences on species diversity, water use, total C stock, among others (González-Roglich 2015).

In theMontedesert, previous research focused on the effect of livestock has determined that population of $P$. flexuosa in cattle-grazed areas present greater proportions of seedlings and saplings (Aschero and García 2012). Also, no differences have been reported in population growth rate between grazed and undisturbed Prosopis woodlands (Aschero et al. 2016), probably due to the moderate livestock loads. In the study area, the carrying capacity for cow calf production depends on precipitation, but the recommended sustainable stocking rate is between 15 and 26 ha/AU (hectares per animal unit; one animal unit (AU) is defined as a $450 \mathrm{~kg}$ beef cow) (Guevara et al. 2009). Livestock production would not represent an aggressive disturbance for other components of arid forests, like functional diversity of mammal assemblages, as long as it does not produce as big a change as the replacement of vegetation composition and structure (Chillo and Ojeda 2012). It has even been suggested that maintaining appropriate levels of grazing is crucial in arid ecosystems where wild ungulates were abundant in the past (Martorell and Peters 2005).

In the present research, we explored the effects of anthropic disturbances as the main determinants of population stages-based structure of $P$. flexuosa in woodlands of Monte 
bioregion. In summary, our results indicate that the combination of low or intermediate intensities of grazing and high wood extraction generates a woodland structure characterized by few seedlings, and many saplings and adult trees of small size. This structure could be sustained for a very long time given the longevity of $P$. flexuosa ( 250 years) and the expected regeneration by climatic pulses for desert species (Holmgren et al. 2006; Morales and Villalba 2012).

Some considerations about the study should be considered. We could observe a modified structure of the woodland in areas with chronic disturbances. But the effects in the exclusive area of wood extraction were more intense than effects in rangelands. In the study area, wood removal is focused on a small surface around the human settlement. Hence, in this focal area the effect is more intense than the effect produced by grazing, which is distributed over a bigger area. Trees with EBD greater than $60 \mathrm{~cm}$ were not found in wood removal area, probably because of the extraction of individuals or cohorts throughout the history of use. On the other hand, large variation in GLMM was associated to site as random effects $(\sim 72-78 \%)$, highlighting that site management, its history and local environment heterogeneity is an important variable to consider for woodland structure in the Monte desert. Knowing the mechanisms by which climate and soil factors influence forest dynamics will help to predict the behavior of woodlands concerning human disturbances and climate change.

Wood is a central component for the conservation of biodiversity in woodlands ecosystems. Although there is an extensive knowledge of the ecological importance of wood in boreal and temperate forests both for nutrient cycling and for habitats provision of different organisms (Harmon et al. 1986; Seibold et al. 2015), research is still scarce in arid ecosystems (Vázquez et al. 2011). Moreover, preliminary studies have demonstrated that wood removal does not have negative effects on the cover, richness and composition of understory plants of Prosopis woodlands (Vázquez et al. 2011). However, the history of livestock use in these woodlands may have masked the effect of wood extraction. Wood management should be included in ecosystem management of woodlands in order to ensure biodiversity conservation and provision of ecosystems services. Thus, it is advisable to deepen the knowledge about the role of wood in drylands and the consequences of its removal on ecological processes.

\section{Management considerations}

Since our results indicate that the combination of high intensities of grazing and wood extraction has a negative effect on all stages, the spatial or temporal separation of these activities or the maintained of moderate intensities of disturbances could reduce the risk for forest conservation, especially if more vulnerable tree life stages are considered. Considering that low or moderate grazing intensities combined with high extraction intensities had a positive effect on the abundance of all classes, the planned management of grazing and wood extraction intensities could help to improve the woodland structure. Woodland patches presenting high density of small multi-stemmed trees, distributed throughout disturbed areas, could be thinned to provide wood for local use (Alvarez 2008). Practices such as thinning would also help to optimize the distribution of diameter classes in the woodland structure and they have shown positive effects in stimulating growth in Prosopis spp. because tree spacing reduces competition (Cornejo-Oviedo et al. 1991; Patch and Felker 1997). Considering mean density of stands without disturbances as a reference, some stems and trees in disturbed stands can be removed to achieve a density of 200 trees/ha. Studies conducted in Prosopis spp. natural stands have shown the greatest growth rate with a density of 100 trees/ha (Patch and Felker 1997). Tree spacing could better drive biomass production and increase crown diameter, improving wood production. Besides, P. flexuosa is a heliophilous tree with low tolerance to shade, whose internal branches dry and remain on the tree (Alvarez et al. 2011b). Regulated removal of wood can enhance the entrance of light to the crown improving growth (Alvarez et al. 2011b). Woodlands of Central Monte have the capacity for firewood production (Alvarez et al. 2011a), so the planned removal of standing wood would be a possible activity in arid lands without grazing.

The reserve integrates the Man and Biosphere Reserve Program of UNESCO, where the development of strategies for biodiversity conservation and sustainable use is encouraged. But the reserve is also within 
the Native Forest Territorial Planning Law as the First Conservation Category (Villagra and Alvarez 2019). Whence, firewood and woodland products extraction is prohibited. Even though the inhabitants of the reserve have historically depended on wood as a fuel to meet their energy needs, the access to this resource has been restricted. Occasionally, the inhabitants' annual wood requirement is complemented with wood from road cleaning (P. Cuello, personal communication). There is also an incipient use of other energy sources as electricity and solar energy (Campos et al. 2019), but wood remains the main fuel in rural communities. Thus, planning the use of woodland resources jointly with inhabitants is an effective management tool that should be developed in arid lands (Alvarez et al. 2011b). The study site presents a favorable scenario for the development of co-management practices between inhabitants and conservation agents. Application of management options should contribute to enhance provision of ecosystem services of Prosopis sp. woodlands without risking regeneration persistence and improving woodland structure.

Acknowledgements. This work was supported by the National Agency for Scientific and Technological Promotion of Argentina (PICT 2017-2154), Secretary of Science, Technology and Postgraduate - U.N. Cuyo (SECTyP Program 2016 and SIIP 2018) and a graduate fellowship from CONICET to CS. We thank to the staff of Nacunán Reserve and the owner and families in charge of the private ranches for allowing us to work there. We thank L. Alvarez, J. Chamorro, D. Severini, S. Mendoza, S. Galli, J. Valsechi, L. Larramendy, G. Franco and M. Alarcón for help with data collection in the field. We thank E. Barrio for provided the poles' photos. We thank E. Moreschi and C. Pissolito for assisting us in drafting the English version.

\section{REFERENCES}

Abraham, E. M., and M. R. Prieto. 1999. Vitivinicultura y desertificación en Mendoza. Pp. 109-135 in B. García Martínez (ed.). Estudios de historia y ambiente en América: Argentina, Bolivia, México, Paraguay, México. Instituto Panamericano de Geografía e Historia (IPGH), Colegio de México, México.

Abraham, E. M., H. F. del Valle, F. Roig, L. Torres, J. O. Ares, F. Coronato, and R. Godagnone. 2009. Overview of the geography of the Monte Desert biome (Argentina). Journal of Arid Environments 73(2):144-153. https://doi.org/ 10.1016/j.jaridenv.2008.09.028.

Aguiar, M. R., and O. E. Sala. 1999. Patch structure, dynamics and implications for the functioning of arid ecosystems. Trends in Ecology and Evolution 14(7):273-277. https://doi.org/10.1016/S0169-5347(99)01612-2.

Albuquerque, U. P., P. H. S. Gonçalves, W. S. Ferreira Júnior, L. S. Chaves, R. C. da Silva Oliveira, T. L. L. da Silva, G. C. dos Santos, and E. de Lima Araújo. 2018. Humans as niche constructors: Revisiting the concept of chronic anthropogenic disturbances in ecology. Perspectives in Ecology and Conservation 16:1-11. https://doi.org/10.1016/ j.pecon.2017.08.006.

Alvarez, J. A. 2008. Bases ecológicas para el manejo sustentable del bosque de algarrobos (Prosopis flexuosa D. C.) en el noreste de Mendoza. Argentina. Título obtenido: Dr. En Ciencias Biológicas. Universidad Nacional del Comahue. Río Negro, Argentina. Pp. 169.

Alvarez, J. A., P. E. Villagra, R. Villalba, M. A. Cony, and M. Alberto. 2011b. Wood productivity of Prosopis flexuosa D.C. woodlands in the central Monte: Influence of population structure and tree-growth habit. Journal of Arid Environment 7:7-13. https://doi.org/10.1016/j.jaridenv.2010.09.003.

Alvarez, J. A., P. E. Villagra, E. M. Cesca, F. Rojas, and S. Delgado. 2015. Estructura, distribución y estado de conservación de los bosques de Prosopis Flexuosa del Bolsón de Fiambalá (Catamarca). Boletín de la Sociedad Argentina de Botánica 50(2):193-208. https://doi.org/10.31055/1851.2372.v50.n2.11663.

Alvarez, J. A., and P. E. Villagra. 2009. Prosopis flexuosa DC. (Fabaceae, Mimosoideae). Kurtziana 35(1):49-63.

Alvarez, J. A., P. E. Villagra, and R. Villalba. 2011a. Factors controlling wood availability and branch decay in two Prosopis woodlands in the Central Monte, Argentina. Forest Ecology and Management 262(4):634-645. https://doi.org/ 10.1016/j.foreco.2011.04.032.

Amahowe, I. O., O. G. Gaoue, A. K. Natta, C. Piponiot, I. C. Zobiand, and B. Hérault. 2018. Functional traits partially mediate the effects of chronic anthropogenic disturbance on the growth of a tropical tree. AoB Plants 10(3):ply036. https://doi.org/10.1093/aobpla/ply036.

Archer, S. R., E. M. Andersen, K. I. Predick, S. Schwinning, R. J. Steidl, and S. R. Woods. 2017. Woody plant encroachment: causes and consequences. Pp. 25-84 in Rangeland systems. Springer, Cham. https://doi.org/10.1007/978-3-319-4670922.

Aschero, V., W. F. Morris, D. P. Vázquez, J. A. Alvarez, and P. E. Villagra. 2016. Demography and population growth rate of the tree Prosopis flexuosa with contrasting grazing regimes in the Central Monte Desert. Forest Ecology and Management 369:184-190. https://doi.org/10.1016/j.foreco.2016.03.028.

Aschero, V., and D. García. 2012. The fencing paradigm in woodland conservation: Consequences for recruitment of a semi-arid tree. Applied Vegetation Science 15(3):307-317. https://doi.org/10.1111/j.1654-109X.2011.01180.x. 
Asner, G., C. Borghi, and R. Ojeda. 2003. Desertification in central Argentina: changes in ecosystem carbon and nitrogen from imaging spectroscopy. Ecological Applications 13:629-648. https://doi.org/10.1890/1051-0761(2003)013[0629: DICACI]2.0.CO;2.

Barton, K. 2020. MuMIn: Multi-Model Inference. R package version 1.43.17. URL: cran.r-project.org/ package=MuMIn.

Bastin, J., N. Berrahmouni, A. Grainger, D. Maniatis, D. Mollicone, et al. 2017. The extent of forest in dryland biomes. Science 356(6338):635-638. https://doi.org/10.1126/science.aam6527.

Bates, D., M. Mächler, B. Bolker, and S. Walker. 2014. Fitting Linear Mixed-Effects Models Using lme4. Journal of Statistical Software. https://doi.org/10.18637/jss.v067.i01.

Campos, C. M., C. Gimenez, C. Szymañski, and L. Torres. 2019. El uso de los bienes naturales comunes por pobladores dentro de áreas protegidas: el caso de la madera muerta en bosques de Prosopis flexuosa de la Reserva MaB Ñacuñán (Mendoza, Argentina) in Libro de Memorias del V Congreso Latinoamericano y III Congreso Ecuatoriano de Etnobiología, edited by SEEB. Quito, Ecuador. URL: portalseeb.wordpress.com/memorias-congresos.

Campos, C. M., and R. A. Ojeda. 1997. Dispersal and germination of Prosopis flexuosa (Fabaceae) seeds by desert mammals in Argentina. Journal of Arid Environments 35(4):707-714. https://doi.org/10.1006/jare.1996.0196.

Capitanelli, R. 1972. Geomorfología y clima de la provincia de Mendoza. Boletín de la Sociedad Argentina de Botánica 13:15-48.

Cesca, E. M., P. E. Villagra, and J. A. Alvarez. 2014. From forest to shrubland: Structural responses to different fire histories in Prosopis flexuosa woodland from the Central Monte (Argentina). Jounal of Arid Environments 110:1-7. https://doi.org/10.1016/j.jaridenv.2014.05.025.

Chillo, V., and R. A. Ojeda. 2012. Mammal functional diversity loss under human-induced disturbances in arid lands. Journal of Arid Environments 82:95-102. https://doi.org/10.1016/j.jaridenv.2012.06.016.

Chillo, V., and R. A. Ojeda. 2014. Disentangling ecosystem responses to livestock grazing in drylands. Agriculture Ecosystems and Environment 197:271-277. https://doi.org/10.1016/j.agee.2014.08.011.

Cornejo-Oviedo, E. H., J. M. Meyer, and P. Felker. 1991 Thinning dense sapling stands of mesquite (Prosopis glandulosa var. glandulosa) to optimize timber production and pasture improvement. Forest Ecology and Management 46(3-4): 189-200. https://doi.org/10.1016/0378-1127(91)90231-J.

Cramer, V. A., R. J. Hobbs, and R. J. Standish. 2008. What's new about old fields? Land abandonment and ecosystem assembly. Trends in Ecology and Evolution 23:104-112. https://doi.org/10.1016/j.tree.2007.10.005.

Delignette-Muller, M. L., and C. Dutang. 2015. fitdistrplus: An R Package for Fitting Distributions. Journal of Statistical Software, 64(4), 1-34. URL: jstatsoft.org/v64/i04.

Di Rienzo, J. A., M. G. Balzarini, C. W. Robledo, F. Casanoves, L. A. Gonzalez, and E. M. Tablada. 2008. InfoStat Manual del Usuario. Universidad Nacional de Córdoba, Córdoba, Argentina.

FAO 2016. El Estado De Los Bosques Del Mundo 2016. Los bosques y la agricultura: desafíos y oportunidades en relación con el uso de la tierra. Roma. URL: fao.org/3/a-i5588s.pdf.

González-Loyarte, M. M., M. Menenti, P. Weidema, F. A. Roig, and M. Barton. 2000. Mapping vegetation degradation applying remotely sensed data in the arid zones of Argentina. The northeastern plain of Mendoza. Proceedings of United Nations/International Astronautical Federation Workshop on "Operational Strategy for Sustainable Development using Space". United Nations Committee on the Peaceful Uses of Outer Space and Office for Outer Space Affairs, Sao José dos Campos, Brazil.

González-Roglich, M. 2015. Spatio-Temporal Dynamics of Woody Plant-Cover in Argentine Savannas: Encroachment, Agriculture Conversion and Changes in Carbon Stocks at Varying Scales. Título obtenido: Doctor of Philosophy. Department of Environment in the Graduate School of Duke University. Durham, N. C., United Estates. Pp. 125.

Guevara, J. C., J. B. Cavagnaro, O. R. Estevez, H. N. Le Houérou, and C. R. Stasi. 1997. Productivity, management and development problems in the arid rangelands of the central Mendoza plains (Argentina). Journal of Arid Environments 35:575-600. https://doi.org/10.1006/jare.1996.0194.

Guevara, J. C., E. G. Grünwaldt, O. R. Estevez, A. J. Bisigato, L. J.Blanco, F. N. Biurrun, C. A. Ferrando, C. C. Chirino, E. Morici, B. Fernández, L. I. Allegretti, and C. B. Passera. 2009. Range and livestock production in the Monte Desert, Argentina. Journal of Arid Environment 73:228-237. https://doi.org/10.1016/j.jaridenv.2008.02.001.

Hartig, F. 2020. DHARMa: Residual Diagnostics for Hierarchical (Multi-Level / Mixed) Regression Models. R package version 0.3.3.0. URL: cran.r-project.org/package=DHARMa.

Holmgren, M., et al. 2006. Extreme climatic events shape arid and semiarid ecosystems. Frontiers in Ecology and the Environment 4(2):87-95. https://doi.org/10.1890/1540-9295(2006)004[0087:ECESAA]2.0.CO;2.

Labraga, J. C., and R. Villalba. 2009. Climate in the Monte Desert: Past trends, present conditions, and future projections. Journal of Arid Environments 73(2):154-163. https://doi.org/10.1016/j.jaridenv.2008.03.016.

Leal, I. R., J. M. C. da Silva, M. Tabarelli, and T. E. Lacher. 2005. Changing the Course of Biodiversity Conservation in the Caatinga of Northeastern Brazil. Conservation Biology 19(3):701-706. https://doi.org/10.1111/j.15231739.2005.00703.x.

Lenth, R. V. 2021. emmeans: Estimated Marginal Means, aka Least-Squares Means. R package version 1.6.3. URL: cran.r-project.org/package $=$ emmeans.

Mandle, L., and T. Ticktin. 2012. Interactions among fire, grazing, harvest and abiotic conditions shape palm demographic responses to disturbance. Journal of Ecology 100(4):997-1008. https://doi.org/10.1111/j.1365-2745.2012.01982.x.

Malagnoux, M., E. H. Sene, and N. Atzmon. 2007. Bosques, árboles y agua en las tierras áridas: Un equilibrio delicado. 
Unasylva 58(229):24-29.

Martorell, C., and E. M. Peters. 2005. The measurement of chronic disturbance and its effects on the threatened cactus Mammillaria pectinifera. Biological Conservation 124(2):199-207. https://doi.org/10.1016/j.biocon.2005.01.025.

Meglioli, P. A., J. N. Aranibar, P. E. Villagra, J. A. Alvarez, and E. G. Jobbágy. 2014. Livestock stations as foci of groundwater recharge and nitrate leaching in a sandy desert of the Central Monte, Argentina. Ecohydrology 7(2): 600-611. https://doi.org/10.1002/eco.1381.

Morales, M. S., and R. Villalba. 2012. Influence of precipitation pulses on long-term Prosopis ferox dynamics in the Argentinean intermontane subtropics. Oecologia 168(2):381-392. https://doi.org/10.1007/s00442-011-2087-9.

Morrissey, R. C., M. A. Jenkins, and M. R. Saunders. 2014. Accumulation and connectivity of coarse woody debris in partial harvest and unmanaged relict forests. PloS one 9(11):e113323. https://doi.org/10.1371/journal.pone.0113323.

Muñoz-Rojas, M., T. E. Erickson, D. C. Martini, K. W. Dixon, and D. J. Merritt. 2016. Climate and soil factors influencing seedling recruitment of plant species used for dryland restoration. Soil 2:287-298. https://doi.org/10.5194/soil-2-2872016.

Nakagawa, S., and H. Schielzeth. 2013. A general and simple method for obtaining $\mathrm{R}^{2}$ from generalized linear mixedeffects models. Methods in Ecology and Evolution 4(2):133-142. https://doi.org/10.1111/j.2041-210x.2012.00261.x.

Patch, N. L., and P. Felker. 1997. Silvicultural treatments for sapling mesquite (Prosopis glandulosa var. glandulosa) to optimize timber production and minimize seedling encroachment. Forest Ecology and Management 96(3):231-240. https://doi.org/10.1016/S0378-1127(97)00041-8.

Piraino, S., E. M. Abraham, M. A. Hadad, D. Patón, and F. A. Roig Juñent. 2016. Anthropogenic disturbance impact on the stem growth of Prosopis flexuosa DC forests in the Monte desert of Argentina: A dendroecological approach. Dendrochronologia 42:63-72. https://doi.org/10.1016/j.dendro.2017.01.001.

Podlaski, R., T Sobala, and M. Kocurek. 2019. Patterns of tree diameter distributions in managed and unmanaged Abies alba Mill. and Fagus sylvatica L. forest patches. Forest Ecology and Management 435:97-105. https://doi.org/10.1016/ j.foreco.2018.12.046.

R Core Team. 2018. R: A Language and Environment for Statistical Computing. Vienna, Austria: R Foundation for Statistical Computing. URL: r-project.org.

Ribeiro, E. M. S., V. Arroyo-Rodríguez, B. A. Santos, M. Tabarelli, and I. R. Leal. 2015. Chronic anthropogenic disturbance drives the biological impoverishment of the Brazilian Caatinga vegetation. Journal of Applied Ecology 52(3):611-620. https://doi.org/10.1111/1365-2664.12420.

Rossi, B. E. 2004. Flora y vegetación de la Reserva de Biosfera de Ñacuñán después de 25 años de clausura. Heterogeneidad espacial a distintas escalas. Título obtenido: Dra. En Ciencias Biológicas. Universidad Nacional de Cuyo. Mendoza, Argentina. Pp. 152.

Rossi, B. E., and P. E. Villagra. 2003. Effects of Prosopis flexuosa on soil properties and the spatial pattern of understorey species in arid Argentina. Journal of Vegetation Science 14(4):543-550. https://doi.org/10.1111/j.16541103.2003.tb02181.x.

Snyman, H. A. 2004. Soil seed bank evaluation and seedling establishment along a degradation gradient in a semi-arid rangeland. African Journal of Range and Forage Science 21(1):37-47. https://doi.org/10.2989/10220110409485832.

Tabeni, S., F. A. Yannelli, N. Vezzani, and L. E. Mastrantonio. 2016. Indicators of landscape organization and functionality in semi-arid former agricultural lands under a passive restoration management over two periods of abandonment. Ecological Indicators 66:488-496. https://doi.org/10.1016/j.ecolind.2016.02.019.

Tabeni, S., F. Spirito, and M. F. Miguel. 2017. Native mammals across grazing and restored woodlands: an overview of ecological connectivity in the central monte desert. Mastozoología Neotropical 24(2):301-312.

Tanquilevich, R. F. 1971. Los suelos de la Reserva Ecológica de Nacuñán. Deserta 2:131-206.

Tongway, D., and N. Hindley. 2004. Landscape function analysis: a system for monitoring rangeland function. African Journal of Range and Forage Science 21(2):109-113. https://doi.org/http://dx.doi.org/10.2989/10220110409485841.

Torres, E. 2001. Hidrología o recursos hídricos superficiales y subterráneos. Pp. 35-40 in S. Claver and S. RoigJuñent (eds.). El desierto del Monte: La Reserva de Biósfera de Ñacuñán. IADIZA - MAB - UNESCO, Mendoza, Argentina.

Valone, T. J., and P. Sauter. 2005. Effects of long-term cattle exclosure on vegetation and rodents at a desertified arid grassland site. Journal of Arid Environments 61:161-170. https://doi.org/10.1016/j.jaridenv.2004.07.011.

Vázquez, D. P., J. A. Alvarez, G. Debandi, J. N. Aranibar, and P. E. Villagra. 2011. Ecological consequences of deadwood extraction in an arid ecosystem. Basic and Applied Ecology 12(8):722-732. https://doi.org/10.1016/ j.baae.2011.08.009.

Villagra, P. E., and R. Villalba. 2001. Estructura poblacional del algarrobal de la Reserva de Nacuñán. Pp. 71-75 en S. Claver and S. Roig-Juñent (eds.). El desierto del Monte: La Reserva de Biósfera de Ñacuñán. IADIZA - MAB UNESCO, Mendoza, Argentina.

Villagra, P. E., M. A. Cony, N. G. Mantován, B. E. Rossi, M. Loyarte González, and R. Villalba. 2004. Ecología y manejo de los algarrobales de la Provincia Fitogeográfica del Monte. Pp. 2-32 in M. F. Arturi, J. L. Frangi and J. F. Goya (eds.). Ecología y Manejo de Bosques Nativos de Argentina. Editorial Universidad Nacional de La Plata, Buenos Aires, Argentina.

Villagra, P. E., R. Villalba, and J. A. Boninsegna. 2005. Structure and growth rate of Prosopis flexuosa woodlands in two contrasting environments of the central Monte desert. Journal of Arid Environments 60(2):187-199. https://doi.org/ 10.1016/j.jaridenv.2004.03.016. 
Villagra, P. E., G. E. Defossé, H. F. del Valle, S. Tabeni, M. Rostagno, E. Cesca, and E. M. Abraham. 2009. Land use and disturbance effects on the dynamics of natural ecosystems of the Monte Desert: Implications for their management. Journal of Arid Environments 73(2):202-211. https://doi.org/10.1016/j.jaridenv.2008.08.002.

Villagra, P. E., and J. A. Alvarez. 2019. Determinantes ambientales y desafíos para el ordenamiento forestal sustentable en los algarrobales del Monte, Argentina. Ecología Austral 29(1):146-155. https://doi.org/10.25260/EA.19.29.1.0.752.

Whitford, W. G., and B. D. Duval. 2019. Ecology of desert systems. Academic Press.

Zar, J. H. 2010. Biostatistical Analysis. 5rd. Ed Hall P. New Jersey: Upper Saddle River. 